\title{
PERCEPTIONS
}

\author{
Volume 5, Number 1
}

Fall 2018

\section{ONWARD AND UPWARD}

\section{TUISSA Temple Undergraduate History and Social Sciences Association}

(C) 2019 Temple University Undergraduate History and Social Sciences Association, all rights reserved ISSN: 2639-6750

Cover photo: "Unite" by Barbara Jones-Hogu 


\section{Letter from the Editor}

Dear reader:

Once again, we are proud to present yet another edition of Perceptions. To see the journal grow so much since its inception in 2009 is truly an amazing feat. On behalf of the Temple Undergraduate History and Social Sciences Association, we are proud to continue serving Temple's first studentrun undergraduate research journal--as a platform for exhibiting the finest undergraduate research in history and the social sciences.

For this edition, we decided to revolve around the themes of progress and advancement. Throughout various events in history, there is always a push for humanity to create a more ideal and prosperous society. While there are setbacks, we never stop to strive for a future more inclusive and fairer for everyone around us. As President Franklin D. Roosevelt had said, "The point in history at which we stand is full of promise and danger. The world will either move forward toward unity and widely shared prosperity - or it will move apart." Looking back, we want to appreciate and acknowledge all the efforts of everyone who dreamed of conquering adversity and hardship. With our title, "Onward and Upward," we rise to meet that challenge.

I would like to thank all the individuals who made this project possible. From the Temple University Library Press to the Department of History, we could not have done it without the support of various outstanding individuals. A special thanks goes to Annie Johnson for continuing to help Perceptions move forward to reaching new heights, both in outreach and technology. This edition of Perceptions is the first issue to use the new OJS 3.0 platform, upgrading to a more userfriendly version that will keep the journal moving towards the future.

We hope that you will enjoy this edition as much as those involved had in creating it.

Sincerely,

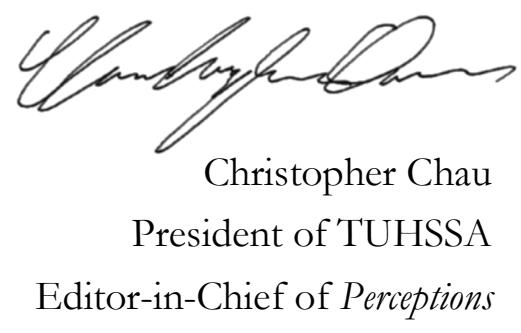




\section{Inside Vol. 5 No. 1}

Helpless Martyr or Hardened Mambisa: Race, Gender, and Agency in the Cisneros Affair Eleanor Andersen, Senior, History/Secondary Education

Impact of Compulsory Sexuality on LGB and Asexual Media Consumers Selena Baugh, Junior, Sociology/African American Studies

Deciphering Fake News: Navigating Today's News Standards

Christina Borst, Junior, Strategic Communication/Political Science

Education, Self-Importance, and the Propensity for Political Participation Lucy Caffrey-Maffei, Recent Graduate, Sociology/Spanish

The Newtown Line: Analyzing a Geography of Abandonment in Suburban Philadelphia Noab DeSimone, Junior, Geography \& Urban Studies/Philosophy

Hidden in Plain Sight: The American Indian Movement and the Revival of the Nanticoke Lenni-Lenape, 1969-1982

Ashton Dunkley, Senior, Anthropology/History

Orchards During War: Braceros in the Northwest

John Fabian, Junior, History

Taking a Knee to Take a Stand: An Analysis of The Bhagavad Gita's Application to the Take a Knee Movement

Srikar Katta, Freshman, Mathematical Economics

Social Media: A Breeding Ground for Energy or Apathy?

Liana King, Sophomore, Communication \& Social Influence

Ethnographic Observations at Christ Church Burial Grounds

Julie Lieren₹, Senior, Antbropology/Art History

The Effects of Chavez's Populism on Today's Venezuela

Italia Messina, Sophomore, Global Studies/Political Science

Unbought and Unbossed: The National Political Congress of Black Women Andrea Morales, Junior, History

Associationalism and Panopticism in American Democracy: An Analysis of Jewish Power Daniel Ramey, Junior, History/Economics 


\title{
Editorial Team
}

\section{Editor-in-Chief}

Christopher Chau

Senior, History \& Political Science Major, French Minor

\section{Executive Editors}

Ellen Taraskiewicz

Senior, History Major, Jewish Studies Minor

Isabelle Heller

Freshman, History Major

\section{Associate Editors}

Benjamin Slesinger

Senior, Criminal Justice Major, Religion Minor

John Fabian

Junior, History Major

Kyle Baskin

Junior, English Major, History Minor

\section{Assistant Editors}

\author{
Pearl Joslyn \\ Senior, History \& Global Studies Major \\ Julius Nathan Fortaleza Klinger \\ Senior, History \& Secondary Education Major \\ Kathleen Elizabeth Kogut \\ Senior, History Major, Criminal Justice Minor \\ Benjamin Aitoumeziane \\ Junior, Political Science \& Economics Major \\ Katherine Weaver \\ Junior, Political Science \& Global Studies
}

